\title{
Arterial hypertension and associated factors in patients submitted to myocardial revascularization*
}

\author{
Hipertensão arterial e fatores associados em pessoas submetidas \\ à cirurgia de revascularização do miocárdio \\ Hipertensión arterial y factores asociados en personas sometidas \\ a la cirugía de revascularización del miocardio
}

Flávia Cortez Colósimo¹, Alexandre Gonçalves de Sousa ${ }^{2}$, Gilmara Silveira da Silva ${ }^{3}$, Raquel Ferrari Piotto ${ }^{4}$, Angela Maria Geraldo Pierin ${ }^{5}$

\footnotetext{
* Extracted from a thesis entitled "Avaliação de uma coorte de pacientes submetidos à cirurgia de revascularização do miocárdio: evolução clínica de hipertensos"; Graduate Program in Adult Health Nursing, Escola de Enfermagem, Universidade de São Paulo, 2015.

${ }^{1} \mathrm{PhD}$ student; Graduate Program in Adult Health Nursing, Escola de Enfermagem, Universidade de São Paulo; São Paulo, SP, Brazil.

${ }^{2}$ Medical researcher; Research Center, Hospital Beneficência Portuguesa; São Paulo, SP, Brazil.

${ }^{3}$ MSc student; Escola de Enfermagem,

Universidade de São Paulo; São Paulo, SP, Brazil.

${ }^{4}$ Supervisor, Research Center, Hospital Beneficência Portuguesa; São Paulo, SP, Brazil.

${ }^{5}$ Full Professor, Escola de Enfermagem, Universidade de São Paulo; São Paulo, SP, Brazil.
}

\section{ABSTRACT}

Objective: To identify the prevalence of arterial hypertension and associated factors in patients submitted to myocardial revascularization. Method: Cross-sectional study using the database of a hospital in São Paulo (SP, Brazil) containing 3010 patients with coronary artery disease submitted to myocardial revascularization. A multiple logistic regression was performed to identify variables independently associated with hypertension (statistical significance: $\mathrm{p}<0.05)$. Results: Prevalence of hypertension was $82.8 \%$. After the variables were adjusted, the associated factors were as follows: age, odds ratio (OR): $\mathrm{OR}=1.01$; 95\% confidence interval (CI): CI:1.00-1.02; female gender: (OR=1.77;CI:1.39-2.25); brown-skin race: $(\mathrm{OR}=1.53 ; \mathrm{CI}: 1.07-2.19)$; obesity: $(\mathrm{OR}=1.53 ; \mathrm{CI}: 1.13-2.06)$; diabetes: $(\mathrm{OR}=1.90 ; \mathrm{CI}: 1.52-2.39)$; dyslipidemia: $(\mathrm{OR}=1.51 ; \mathrm{CI}: 1.23-1.85)$; and creatinine>1.3: $(\mathrm{OR}=1.37 ; \mathrm{CI}: 1.09-1.72)$. Conclusion: A high prevalence of arterial hypertension and association with both non-modifiable and modifiable factors was observed.

\section{DESCRIPTORS}

Hypertension; Prevalence; Myocardial Revascularization; Risk factors.
Correspondence Addressed to:

Angela Maria Geraldo Pierin

Av Dr Enéas de Carvalho Aguiar, 419 - Cerqueira Cesar CEP 05403-000, São Paulo, SP, Brazil.

pierin@usp.br
Received: 10/31/2014

Approved: 01/12/2015 


\section{INTRODUCTION}

In Brazil, cardiovascular diseases are the leading cause of death. They are responsible for a high number of hospital admissions and result in high health and social costs. In the period Jan-Jun 2014, 554,850 admissions for diseases in the circulatory system were registered in the Unified Health System, and $\mathrm{R} \$ 1,253,350,156.33$ were spent on these diseases ${ }^{(1)}$.

Cardiovascular risk factors were first identified in the classic study by Framingham. He revealed the importance of factors including arterial hypertension, diabetes, elevated LDL cholesterol, low HDL cholesterol, smoking, family history, obesity, and sedentarism as factors strongly related to atherosclerosis ${ }^{(2)}$. Recently, the INTERHEART casecontrol study, which was conducted in 52 countries (five continents) listed nine factors, including hypertension, as being of greatest risk for the development of acute myocardial infarction ${ }^{(3)}$. In a multicenter study conducted in 12 hospitals in the metropolitan region of São Paulo (SP, Brazil), arterial hypertension has emerged as a potent risk factor for acute myocardial infarction, with an odds ratio of 3.26 in relation to non-hypertensive individuals ${ }^{(4)}$.

The role of hypertension as a risk factor for cardiovascular disease and its high prevalence in many countries in the world makes this disease a considerable public health problem. Although a Brazilian study on its prevalence is not available, about $30 \%$ of the Brazilian adult population is estimated to be hypertensive, and this rate is doubled in the elderly ${ }^{(5)}$. Treatment in the pharmacological and nonpharmacological modalities was shown to be effective, but control of arterial hypertension is hardly satisfactory ${ }^{(6)}$. Sustained high pressure levels cause damage in target organs, with serious complications such as myocardial infarction, stroke, and kidney failure.

Regarding treatment of coronary heart disease, much progress was achieved in terms of either medicines for clinical treatment or technologies for percutaneous and surgical approach. Surgery for myocardial revascularization has been widely carried out all over the world by virtue of the high technical development and favorable results. However, the results also depend on the clinical condition of the patient, who often has multiple factors for cardiovascular risk and associated comorbidities ${ }^{(7-8)}$.

Although Brazilian studies have described the clinical and demographic profile of patients submitted to surgical myocardial revascularization $^{(8-11)}$, no study described association of arterial hypertension with other risk factors and comorbidities in this population. The purpose of this study was to identify prevalence of arterial hypertension and associated factors in coronary artery disease patients submitted to myocardial revascularization surgery.

\section{METHOD}

This study was conducted with data from the database for myocardial revascularization surgery of a large hospital in the city of São Paulo (SP, Brazil). The database contains information about 3010 patients who were submitted to this type of surgery in the period July 2009-Jul 2010.
Data for sociodemographic characteristics, cardiovascular risk factors, associated diseases, as well as characteristics of the surgical procedure, complications, and postoperative outcome (discharge or death) were collected from medical records. A structured questionnaire was completed by trained researchers. Subsequently, data were entered into a spreadsheet prepared with the Delphi program.

Only preoperative characterization data were used in this study. Therefore, it is configured up as a cross-sectional study. Hypertension, defined as a history of hypertension, registered in medical records, and categorized as yes or no, was considered as a dependent variable. The independent variables were divided into sociodemographic variables (gender, age, race, and source of funding for hospital admission) cardiovascular risk factors (diabetes, dyslipidemia, smoking, obesity, and family history of coronary artery disease), and other diseases (chronic obstructive pulmonary disease, chronic kidney disease, peripheral arterial disease, and cerebrovascular disease). For characterization of patient race, similarly to what was used in population censuses by the Instituto Brasileiro de Geografia e Estatística (IBGE), we used self-defined skin color as informed by the individual for his/her identification with the hospitalization service. The sources for funding hospitalization were dichotomized in SUS, for resources of the Unified Health System, or non-SUS, for resources of either health insurance or private resources. We considered as current smokers individuals who reported smoking in the last month before surgery and former smokers those who have stopped smoking for 30 or more days before surgery. The body mass index (BMI) was calculated by the equation BMI $=\mathrm{w} / \mathrm{h}^{2}$ ( $w$ : weight in $\mathrm{kg} ; b$ : height in $\mathrm{m}$ ), using the weight and height values as measured and registered in the medical records during the medical or nursing anamnesis performed at admission. The following classification was adopted using the values for BMI: normal weight $\left(18.5-24.9 \mathrm{~kg} / \mathrm{m}^{2}\right)$, overweight $\left(25.0-29.9 \mathrm{~kg} / \mathrm{m}^{2}\right)$, and obesity $\left(\geq 30.0 \mathrm{~kg} / \mathrm{m}^{2}\right)^{(12)}$. Diabetes, dyslipidemia, family history of coronary heart disease, and other comorbidities were defined according to the previous history of these conditions as registered in the medical records. The last value of preoperative serum creatinine, as dosed by the hospital clinical laboratory, was also considered.

In the statistical analysis, the chi-square test or Fisher's exact test were used to verify equal proportion of categorical variables between interest groups, and Student's $t$ test was used for continuous variables. In order to estimate the independent effect of the variables on the outcome (arterial hypertension), the variables with values for $p<0.20$ in the bivariate analysis were selected to integrate the multiple logistic regression model. We adopted the statistical significance level of $5 \%$.

The project was approved by the Research Ethics Committee (Protocol No. 658-10) of the institution where the study was conducted.

\section{RESULTS}

All 3010 patients of the institution's database were included in this study. Patients submitted to myocardial 
revascularization were predominantly of the male gender (69.9\%), with an average age of 62.2 years (standard deviation: 9.4).White-skinned individuals (84.6\%) predominated and a large majority of hospital admissions was funded by SUS (92.2\%). Arterial hypertension was present in 2491 patients $(82.8 \%)$.

Table 1 - Sociodemographic variables in hypertensive and non-hypertensive patients submitted to myocardial revascularization - São Paulo, SP, Brazil, 2014.

\begin{tabular}{|c|c|c|c|c|c|c|c|}
\hline \multirow{2}{*}{ Variables } & \multicolumn{2}{|c|}{ Hypertensive patients } & \multicolumn{2}{|c|}{ Non-hypertensive patients } & \multicolumn{2}{|c|}{ Total } & \multirow{2}{*}{$p$ values } \\
\hline & $\mathrm{N}$ & $\%$ & $\mathbf{N}$ & $\%$ & $\mathbf{N}$ & $\%$ & \\
\hline \multicolumn{8}{|l|}{ Genders } \\
\hline Male & 1689 & 67.8 & 416 & 80.2 & 2105 & 69.9 & \\
\hline Female & 802 & 32.2 & 103 & 19.8 & 905 & 30.1 & $<0.000$ \\
\hline \multicolumn{8}{|l|}{ Skin colors } \\
\hline White & 2096 & 84.1 & 451 & 86.9 & 2547 & 84.6 & \\
\hline Brown & 266 & 10.7 & 39 & 7.5 & 305 & 10.1 & \\
\hline Black & 98 & 3.9 & 23 & 4.4 & 121 & 4.0 & \\
\hline Yellow & 31 & 1.2 & 6 & 1.2 & 37 & 1.2 & 0.177 \\
\hline \multicolumn{8}{|l|}{ Funding sources } \\
\hline SUS * & 2305 & 92.5 & 471 & 90.7 & 2776 & 92.2 & \\
\hline Non-SUS & 186 & 7.5 & 48 & 9.3 & 234 & 7.8 & 0.167 \\
\hline Ages, years, mean $(\mathrm{SD})^{*}$ & $62.43(9.47)$ & & $61.08(9.53)$ & & $62.2(9.4)$ & & 0.003 \\
\hline
\end{tabular}

* SUS- Sistema Único de Saúde (Unified Health System); SD- Standard deviation

Table 1 shows sociodemographic characteristics accord- alence of female gender compared with non-hypertensive ing to the groups of hypertensive and non-hypertensive. patients $(\mathrm{p}<0.05)$. Significant association between arterial Hypertensive patients had significantly higher age and prev- hypertension and race or funding source was not observed.

Table 2 - Cardiovascular risk factors and comorbidities in hypertensive and non-hypertensive patients submitted to myocardial revascularization - São Paulo, SP, Brazil, 2014.

\begin{tabular}{|c|c|c|c|c|c|c|c|}
\hline \multirow{2}{*}{ Variables } & \multicolumn{2}{|c|}{ Hypertensive patients } & \multicolumn{2}{|c|}{ Non-hypertensive patients } & \multicolumn{2}{|c|}{ Total } & \multirow{2}{*}{$p$ values } \\
\hline & $\mathbf{N}$ & $\%$ & $\mathbf{N}$ & $\%$ & $\mathbf{N}$ & $\%$ & \\
\hline Yes & 983 & 39.5 & 119 & 22.9 & 1102 & 36.6 & 0.0001 \\
\hline No & 1508 & 60.5 & 400 & 77.1 & 1908 & 63.4 & \\
\hline \multicolumn{8}{|l|}{ Dyslipidemia } \\
\hline Yes & 1159 & 46.5 & 179 & 34.5 & 1338 & 44.5 & $<0.0001$ \\
\hline No & 1332 & 53.5 & 340 & 65.5 & 1672 & 55.5 & \\
\hline \multicolumn{8}{|c|}{ Body Mass Index (Kg/m2)* } \\
\hline Normal & 814 & 33.7 & 187 & 37.2 & 1001 & 34.3 & \\
\hline Overweight & 1078 & 44.6 & 241 & 47.9 & 1319 & 45.1 & \\
\hline Obesity & 526 & 21.7 & 75 & 14.9 & 601 & 20.6 & $<0.001$ \\
\hline \multicolumn{8}{|l|}{ Smoking } \\
\hline Never & 1129 & 45.3 & 216 & 41.6 & 1345 & 44.7 & \\
\hline Stopped & 999 & 40.1 & 205 & 39.5 & 1204 & 40.0 & 0.03 \\
\hline Yes & 363 & 14.6 & 98 & 18.9 & 461 & 15.3 & \\
\hline \multicolumn{8}{|c|}{ Family history Coronary Artery Disease } \\
\hline Yes & 718 & 28.8 & 163 & 31.4 & 881 & 29.3 & 0.239 \\
\hline No & 1773 & 71.2 & 356 & 68.6 & 2129 & 70.7 & \\
\hline \multicolumn{8}{|c|}{ Chronic kidney disease } \\
\hline Yes & 152 & 6.1 & 18 & 3.5 & 170 & 5.6 & 0.01 \\
\hline No & 2339 & 93.9 & 501 & 96.5 & 2840 & 94.4 & \\
\hline \multicolumn{8}{|l|}{ Stroke } \\
\hline Yes & 150 & 6.0 & 18 & 3.5 & 168 & 5.6 & 0.021 \\
\hline No & 2341 & 94.0 & 501 & 96.5 & 2842 & 94.4 & \\
\hline \multicolumn{8}{|c|}{ Peripheral arterial disease } \\
\hline Yes & 131 & 5.3 & 15 & 2.9 & 146 & 4.8 & 0.022 \\
\hline No & 2360 & 94.7 & 504 & 97.1 & 2864 & 95.2 & \\
\hline \multicolumn{8}{|c|}{ Carotid artery disease } \\
\hline Yes & 49 & 2.0 & 5 & 1.0 & 54 & 1.8 & 0.117 \\
\hline No & 2442 & 98.0 & 514 & 99.0 & 2956 & 98.2 & \\
\hline Yes & 74 & 3.0 & 10 & 1.9 & 84 & 2.8 & \\
\hline No & 2417 & 97.0 & 509 & 98.1 & 2926 & 97.2 & 0.189 \\
\hline
\end{tabular}




\begin{tabular}{|c|c|c|c|c|c|c|c|}
\hline \multirow{2}{*}{ Variables } & \multicolumn{2}{|c|}{ Hypertensive patients } & \multicolumn{2}{|c|}{ Non-hypertensive patients } & \multicolumn{2}{|c|}{ Total } & \multirow{2}{*}{$p$ values } \\
\hline & $\mathbf{N}$ & $\%$ & $\mathbf{N}$ & $\%$ & $\mathbf{N}$ & $\%$ & \\
\hline \multicolumn{8}{|c|}{ Chronic lung disease } \\
\hline Yes & 182 & 7.3 & 27 & 5.2 & 209 & 6.9 & 0.086 \\
\hline No & 2309 & 92.7 & 492 & 94.8 & 2801 & 93.1 & \\
\hline \multicolumn{8}{|l|}{ Angina } \\
\hline Yes & 1870 & 75.1 & 368 & 70.9 & 2238 & 74.4 & 0.048 \\
\hline No & 621 & 24.9 & 151 & 29.1 & 772 & 24.6 & \\
\hline \multicolumn{8}{|c|}{ Serum creatinina (mg/dL) } \\
\hline$\leq 1.3$ & 1742 & 69.9 & 392 & 75.5 & 2134 & 70.9 & 0.010 \\
\hline$>1.3$ & 149 & 30.1 & 127 & 24.5 & 876 & 29.1 & \\
\hline
\end{tabular}

Regarding cardiovascular risk factors and other diseases, such as diabetes, dyslipidemia, obesity, chronic kidney disease, previous stroke, and peripheral arterial disease, their presence in hypertensive patients was more frequent than in non-hypertensive patients $(\mathrm{p}<0.05)$. In hypertensive patients, frequency of former smokers and non-smokers $(\mathrm{p}<0.05)$, serum creatinine values above $1.3 \mathrm{mg} / \mathrm{dL}$, and complaints of angina in the preoperative period (Table 2) were also higher than in non-hypertensive patients.
The multiple logistic regression model showed an independent association of sociodemographic variables, some risk factors, and comorbidities with arterial hypertension. Thus, the chance of a patient to have arterial hypertension increases with each year of age, being higher in women and brown-skinned subjects compared to white, obese, diabetic, and dyslipidemic patients, as well as those with serum creatinine higher than 1.3 $\mathrm{mg} / \mathrm{dL}$ (Table 3).

Table 3 - Multiple logistic regression model: variables associated with arterial hypertension in patients submitted to myocardial revascularization - São Paulo, SP, Brazil, 2014.

\begin{tabular}{|c|c|c|c|c|}
\hline \multirow{2}{*}{$\begin{array}{l}\text { Variables } \\
\text { Age }\end{array}$} & \multirow{2}{*}{$\begin{array}{c}\text { OddsRatios } \\
1.01\end{array}$} & \multicolumn{2}{|c|}{$\mathrm{Cl}(95 \%)$} & \multirow{2}{*}{$\begin{array}{c}\text { p values } \\
0.037\end{array}$} \\
\hline & & $1.00-$ & 1.02 & \\
\hline \multicolumn{5}{|l|}{ Gender } \\
\hline Male & 1.00 & & & - \\
\hline Female & 1.77 & $1.39-$ & 2.25 & $<0.001$ \\
\hline \multicolumn{5}{|l|}{ Skin color } \\
\hline White & 1.00 & & & - \\
\hline Black & 1.07 & $0.66-$ & 1.76 & 0.777 \\
\hline Brown & 1.53 & $1.07-$ & 2.19 & 0.020 \\
\hline Yellow & 0.95 & $0.39-$ & 2.33 & 0.903 \\
\hline \multicolumn{5}{|c|}{ Body Mass Index $\left(\mathrm{kg} / \mathrm{m}^{2}\right)$} \\
\hline$<25$ & 1.00 & & & - \\
\hline $25-29.9$ & 1.04 & $0.84-$ & 1.29 & 0.729 \\
\hline$\geq 30$ & 1.53 & $1.13-$ & 2.06 & 0.005 \\
\hline \multicolumn{5}{|l|}{ Diabetes } \\
\hline No & 1.00 & & & - \\
\hline Yes & 1.90 & $1.52-$ & 2.39 & $<0.001$ \\
\hline \multicolumn{5}{|c|}{ Dyslipidemia } \\
\hline No & 1.00 & & & - \\
\hline Yes & 1.51 & $1.23-$ & 1.85 & $<0.001$ \\
\hline \multicolumn{5}{|c|}{ Serum creatinina $(\mathrm{mg} / \mathrm{dL})$} \\
\hline$\leq 1.3$ & 1.00 & & & - \\
\hline$>1.3$ & 1.37 & 1.09 - & 1.72 & 0.007 \\
\hline
\end{tabular}

\section{DISCUSSION}

The main results of this study are related to the high prevalence of arterial hypertension in the study population and its association with modifiable cardiovascular risk factors such as diabetes, dyslipidemia, and obesity. Association between arterial hypertension and non-modifiable biological variables such as age, gender, and race were also observed in this study.

The notable prevalence of arterial hypertension identified in this study (82.8\%) was much higher than that found 
in the general population. This result is somewhat expected, if the known association between arterial hypertension and coronary heart disease is taken into account. Equally high prevalences were reported in other studies also conducted with individuals submitted to myocardial revascularization surgery $^{(8-11)}$ reaching rates as high as $90 \%{ }^{(10)}$.

For the general population, epidemiological studies conducted in different regions of Brazil show a prevalence of arterial hypertension that varies in the range of 23.0$41.4 \%{ }^{(13-16)}$. The variation observed between rates can be explained by the different methodologies used in the studies, as well as the heterogeneity of the study populations. Data from the telephone survey VIGITEL (Monitoring of Risk Factors and Protection for Chronic Diseases by Telephone Survey), which monitors risk factors for chronic diseases in 26 Brazilian capitals and the Federal District, indicate a prevalence of self-reported arterial hypertension of $23.0 \%$ in the population aged over 18 years, ranging from 16.6\% (Boa Vista, RR) to $29.7 \%$ (Rio de Janeiro, RJ) ${ }^{(17)}$. A population-based household survey was conducted in 100 Brazilian municipalities and showed a prevalence of $16.3 \%$ in adults aged below 59 years ${ }^{(18)}$.

Regarding frequency of arterial hypertension in the male and female genders, the results of different investigations are controversial. Although frequency of arterial hypertension has been assumed to be higher among men or even similar between genders until the age of 50 years, occurrence of arterial hypertension among women showed to be higher ${ }^{(19)}$ and its predominance in this gender regardless of age was also demonstrated ${ }^{(20)}$. In the present study, association between arterial hypertension and female gender was observed even after ages were adjusted. Data from the VIGITEL 2012 study showed a higher prevalence of arterial hypertension among women of all age groups in almost all states in Brazil ${ }^{(17)}$. However, it should be considered that studies based on self-reported arterial hypertension can indicate a higher prevalence of this disease among women because they know better their health and seek more for health services than men do. However, we believe that this bias has been minimized in this study, because such patients generally have a previous health monitoring, know their condition, being referred to a tertiary service for specialized surgery.

Our study shows that women have a $10 \%$ increase per year of life in the chance of presenting arterial hypertension. The increase in prevalence of arterial hypertension with progression of age is well established in the literature. Very often, arterial hypertension prevalences greater than $50 \%$ are reported for ages over 50 years, and rates of up to $70 \%$ were found for ages over 70 years ${ }^{(21)}$. Despite to the known increase in prevalence of this disease with advancing age, high rates of arterial hypertension in younger age groups have been reported, possibly influenced by occurrence of overweight in these age groups in the study population ${ }^{(20)}$.

The highest prevalence of hypertension in black-skinned individuals has also been demonstratedin epidemiological studies $^{(15,20)}$. In a recent study conducted in Brazil, a $45.4 \%$ prevalence of arterial hypertension was found in quilombola communities. Such rate is higher than that shown in general population studies ${ }^{(22)}$. The present study shows a higher prevalence of arterial hypertension in mulatto compared with that of white-skinned individuals. We can consider that the strong miscegenation that exists in Brazil and the criterion adopted for definition of race (self-declaration) may have contributed to this result, because individuals selfdeclared as brown-skinned may have characteristics and genetic inheritance of black-skinned individuals.

Beyond the biological aspect related to black-skinned individuals, many authors call attention to the low education and income which are frequent among them. In a study conducted in Salvador (BA, Brazil), the authors state that an improvement in the educational level and, therefore, in the socioeconomic level could minimize the effects of racial influence on the high prevalence of cardiovascular risk factors found in that population ${ }^{(23)}$. Possible explanations for the influence of the lower socioeconomic level on health conditions of the population fall on their lack of access to the health system, beyond the lower degree of information and understanding of the disease and their determinants ${ }^{(24)}$. In addition, studies have already shown the negative impact the lower socioeconomic level exerts on physical activity and adoption of a healthy $\operatorname{diet}^{(25)}$. In the present study, the socioeconomic variable was represented by the source of funding of patient surgery, dichotomized into the SUS and non-SUS groups, but association between this variable and arterial hypertension was not demonstrated. Whether the funding source variable used in the study adequately reflects the mentioned aspects (access, information, and understanding) for this sample, it could be questioned. A publication used the same sample of this study and showed that other preoperative clinical characteristics were not different for the SUS and non-SUS groups ${ }^{(26)}$.

Regarding the modifiable risk factors, the present study corroborates evidence from other studies that show association of arterial hypertension with diabetes, altered levels of triglycerides and cholesterol, and overweight ${ }^{(27)}$. The frequent simultaneity of these factors could express a common pathophysiological mechanism. The Salvador (BA, Brazil) study showed that arterial hypertension alone, i.e., in the absence of other cardiovascular risk factors, occurred in only $0.9 \%$ of both men and women ${ }^{(23)}$.

A population study on risk factors for arterial hypertension in a city in the countryside of São Paulo State showed a significantly higher prevalence of diabetes among hypertensive patients (odds ratio $=6.54)^{(21)}$.

A study on factors associated with arterial hypertension in river communities involved case series with specific features, potentially different from those of the general population. However, after adjusted analysis it showed association of arterial hypertension with overweight, elevated glycemia, and age over 60 years in men, and with age and high triglyceride and glucose blood levels in women ${ }^{(28)}$.

Overweight is currently a global epidemic. In this study, overweight and obesity were pooled (65.7\% of subjects), being the second most prevalent cardiovascular risk factor. In obese individuals, the chance of hypertension 
was $53 \%$ greater than in eutrophic ones. Several studies on factors associated with hypertension also revealed such relationship ${ }^{(16,20-21)}$.

The present study also evidenced occurrence of higher levels of serum creatinine in hypertensive compared with non-hypertensive patients even after the variables were adjusted. Although the study has a cross-sectional character and does not allow to establish causal relationships between the two variables, this fact points to the existence of target organ injury, indicating a worse renal function in hypertensive patients. Similarly, the study demonstrated a significantly higher hypercreatinemia in hypertensive patients (odds ratio $=5.42$ ) of a general adult population, in addition to a 4.5 times greater chance of renal dysfunction (defined as a creatinine clearance $<60 \mathrm{ml} / \mathrm{min}$ ) in hypertensive individuals ${ }^{(21)}$. In the present study, other target organ injuries such as histories of stroke, peripheral arterial disease, and chronic kidney disease were significantly associated with arterial hypertension, demonstrating the deleterious role of hypertension on specific body organs and putting the hypertensive coronary patient at a level of greater clinical severity.

The evidence of aggregation of cardiovascular risk factors shown in this study reinforces the recommendation that health education strategies aimed to reduce cardiovascular risk should cover several risk factors together. Although in the national guidelines ${ }^{(5)}$ of arterial hypertension the changes in lifestyle are described as non-pharmacological interventions, and its orientation is considered a role of the multidisciplinary health team, this tool is still underutilized. In a survey conducted in the city of Sao Paulo, just over half of the hypertensive patients interviewed stated they had received guidance on forms of non-pharmacological treatment for hypertension in health services ${ }^{(13)}$. In another nationwide study, only $45.4 \%$ of the hypertensive adults received guidance to maintain ideal weight and $47.9 \%$ to perform physical activity ${ }^{(18)}$. On the other hand, controlled studies conducted in primary care units showed a significant improvement in the control of risk factors, especially in blood pressure levels, after the educational program for hypertensive patients was implemented ${ }^{(29-30)}$.

Study limitations include cross-sectional design, which allows to identify association between variables without however establishing causal relationships, and use of data collected through medical records, which allows the bias of lack of registration.

\section{CONCLUSION}

While our results show an association between arterial hypertension and other cardiovascular risk factors, especially factors sensitive to lifestyle modifications, in patients submitted to myocardial revascularization surgery, they reinforce the need to implement comprehensive educational strategies and at all levels of health care.

In the hospital context of myocardial revascularization surgery, patient care is performed by a multidisciplinary team. Nurses play an extremely important role, as these professionals assist patients continuously during all their stay. Therefore, in addition to the technical skills necessary for nurses to take care of surgical patients, they must take the role of co-educators in health, guiding and encouraging patients to adopt healthy habits that will reflect in all risk factors and comorbidities present in individuals with coronary artery disease.

\section{RESUMO}

Objetivo: Identificar a prevalência da hipertensão arterial e fatores associados em pacientes submetidos à cirurgia de revascularização miocárdica. Método: Estudo transversal utilizando banco de dados de um hospital em São Paulo-SP, Brasil contendo 3010 coronariopatas submetidos à revascularização miocárdica. Procedeu-se à regressão múltipla para identificação das variáveis independentemente associadas à hipertensão, considerando-se significância estatística $\mathrm{p}<0,05$. Resultados: A prevalência de hipertensão foi de 82,8\% e os fatores associados, após ajuste das variáveis, foram: idade Oddsratio (OR) = 1,01, intervalo de confiança 95\% (IC): 1,00-1,02; sexo feminino $\mathrm{OR}=1,77$, IC:1,39-2,25; raça parda $\mathrm{OR}=1,53$, IC:1,07-2,19; obesidade OR = 1,53, IC:1,13-2,06; diabetes OR = 1,90, IC:1,52-2,39; dislipidemia OR = 1,51, IC:1,23-1,85; e creatinina $>1,3$ OR =1,37, IC:1,09-1,72. Conclusão: Verificou-se elevada prevalência de hipertensão arterial e associação tanto com fatores não modificáveis, como com fatores modificáveis.

\section{DESCRITORES}

Hipertensão; Prevalência; Revascularização Miocárdica; Fatores de risco.

\section{RESUMEN}

Objetivo: Identificar la prevalencia de la hipertensión arterial y los factores asociados en pacientes sometidos a la cirugía de revascularización miocárdica. Método: Estudio transversal utilizando banco de datos de un hospital en São Paulo-SP, Brasil, conteniendo a 3010 coronariopatas sometidos a la revascularización miocárdica. Se procedió a la regresión múltiple para la identificación de las variables independientemente asociadas con la hipertensión, considerándose significación estadística p< 0,05. Resultados: La prevalencia de hipertensión fue del 82,8\% y los factores asociados, después del ajuste de las variables, fueron: edad Oddsratio $($ OR) = 1,01, intervalo de confianza del 95\% (IC): 1,00-1,02; sexo femenino OR =1,77, IC:1,39-2,25; raza morena OR = 1,53, IC:1,07-2,19; obesidad $\mathrm{OR}=1,53$, IC:1,13-2,06; diabetes $\mathrm{OR}=1,90$, IC:1,52-2,39; dislipidemia OR = 1,51, IC:1,23-1,85; y creatinina>1,3 OR = 1,37, IC:1,09-1,72. Conclusión: Se verificó elevada prevalencia de hipertensión arterial y asociación tanto con factores no cambiables como con factores cambiables.

\section{DESCRIPTORES}

Hipertensión; Prevalencia; Revascularización Miocárdica; Factores de Riesgo. 


\section{REFERENCES}

1. Brasil. Ministério da Saúde. DATASUS. Informações de saúde [Internet]. Brasília; 2014 [citado 2014 out. 22]. Disponível em http://tabnet. datasus.gov.br/cgi/deftohtm.exe? sih/cnv/niuf.def

2. Dawber TR, Meadors GF, Moore Jr FE. Epidemiological approaches to heart disease: the Framingham Study. Am J Public Health Nations Health. 1951;41(3):279-81.

3. Yusuf S, Hawken S, Ounpuu S, Dans T, Avezum A, Lanas F, et al.; INTERHEART Study Investigators. Effect of potencially modifiable risk factors associated with myocardial infarction in 52 countries (the INTERHEART study): case-control study. Lancet. 2004;364(9438):937-52.

4. Avezum A, Piegas LS Pereira JC. Risk factors associated with acute myocardial infarction in the São Paulo metropolitan region: a developed region in a developing country. Arq Bras Cardiol. 2005;84(3):206-13.

5. Sociedade Brasileira de Cardiologia; Sociedade Brasileira de Hipertensão; Sociedade Brasileira de Nefrologia. VI Diretrizes Brasileiras de Hipertensão. Arq Bras Cardiol. 2010;95 Supl. 1:1-51.

6. Pinho NB, Pierin AMG. Hypertension control in Brazilian publications. Arq Bras Cardiol. 2013;101(3):65-73.

7. Head SJ, Kieser TM, Falk V, Huysmans HA, Kappetein AP. Coronary artery bypass grafting, the evolution over the first 50 years. Eur Heart J. 2013;34(37):2862-72.

8. Oliveira EL, Westphal GA, Mastroeni MF. Demographic and clinical characteristics of patients undergoing coronary artery bypass graft surgery and their relation to mortality. Rev Bras Cir Cardiovasc. 2012;27(1):52-60.

9. Feier FH, Sant'Anna RT, Garcia E, Bacco FW, Pereira E, Santos MF, et al. Changes in profile of patients of patients submitted to coronary bypass graft surgery. Rev Bras Cir Cardiovasc. 2005;20(3):317-22.

10. Oliveira TML, Oliveira GMM, Klein CH, Silva NASS, Godoy PH. Mortality and complications of coronary artery bypass grafting in Rio de Janeiro from, 1999 to 2003. Arq Bras Cardiol. 2010;95(3):303-12.

11. Campagnucci VP, Silva AMRP, Pereira WLP, Chamlian EG, Gandra SMA, Rivetti LA. EuroSCORE and the patients undergoing coronary bypass surgery at Santa Casa de São Paulo. Rev Bras Cir Cardiovasc. 2008; 23(2):262-7.

12. Sociedade Brasileira de Hipertensão; Sociedade Brasileira de Cardiologia; Sociedade Brasileira de Endocrinologia e Metabologia; Sociedade Brasileira de Diabetes; Associação Brasileira para o Estudo da Obesidade e Síndrome Metabólica. I Diretriz Brasileira de Diagnóstico e Tratamento da Síndrome Metabólica. Arq Bras Cardiol. 2005;84 Supl.1:1-28.

13. Mion Jr D, Pierin AMG, Bensenor IM, Marin JCM, Costa KRA, Henrique LFO, et al. Hypertension in the city of São Paulo: telephone surveys. Arq Bras Cardiol. 2010;95(1):99-106.

14. Costa JSD, Barcellos FC, Sclowitz ML, Sclowitz IKT, Castanheira M, Olinto MTA, et al. Hypertension prevalence and its associated risk factors in adults: a population-based study in Pelotas, RS, Brazil. Arq Bras Cardiol. 2007;88(1):59-65.

15. Lessa I, Magalhães L, Araújo MJ, Almeida Filho N, Aquino E, Oliveira MMC. Arterial hypertension in the adult population of Salvador (BA) - Brazil. Arq Bras Cardiol. 2006;87(6):747-56.

16. Souza ARA, Costa A, Nakamura D, Mocheti LN, Stevanato Filho PR, Ovando LA. A study on systemic arterial hypertension in Campo Grande, MS, Brazil. Arq Bras Cardiol. 2007;88(4):441-6.

17. Brasil. Ministério da Saúde; Secretaria de Vigilância em Saúde, Departamento de Vigilância de Doenças e Agravos não Transmissíveis e Promoção de Saúde. VIGITEL Brasil 2012: vigilância de fatores de risco e proteção para doenças crônicas por inquérito telefônico. Brasília; 2013.

18. Piccini RX, Facchini LA, Tomasi E, Siqueira FV, Silveira DS, Thumé E, et al. Promotion, prevention and arterial hypertension care in Brazil. Rev Saúde Pública. 2012;46(3):543-50.

19. Lessa I. Epidemiologia da hipertensão arterial sistêmica e da insuficiência cardíaca no Brasil. Rev Bras Hipertens. 2001;8(4):383-92.

20. Ferreira SRG, Moura EC, Malta DC, Sarno F. Frequência de hipertensão arterial e fatores associados: Brasil, 2006. Rev Saúde Pública. 2009;43 Supl. 2:98-106.

21. Cipullo JP, Martin JFV, Ciorlia LAS, Godoy MRP, Cação JC, Loureiro AAC, et al. Hypertension prevalence and risk factors in a Brazilian urban population. Arq Bras Cardiol. 2010;94(4):519-26.

22. Bezerra VM, Andrade ACS, César CC, Caiaffa WT. Comunidades quilombolas de Vitória da Conquista, Bahia, Brasil: hipertensão arterial e fatores associados. Cad Saúde Pública. 2013;29(9):1889-902.

23. Lessa I, Araújo MJ, Magalhães L, Almeida Filho N, Aquino E, Costa MCR. Simultaneidade de fatores de risco cardiovascular modificáveis na população adulta de Salvador (BA), Brasil. Rev Panam Salud Publica. 2004;16(2):131-7.

24. Barros MBA, Francisco PMSB, Zanchetta LM, César CLG. Tendências das desigualdades sociais e demográficas na prevalência de doenças crônicas no Brasil, PNAD: 2003- 2008. Ciênc Saúde Coletiva. 2011;16(9):3755-68.

25. Gidlow C, Johnston LH, Crone D, Ellis N, James D. A systematic review of the relationship between socio-economic position and physical activity. Health Educ J. 2006;65(4):338-67.

26. Silva GS, Sousa AG, Soares D, Colósimo FC, Piotto RF. Evaluation of the length of hospital stay in cases of coronary artery bypass graft by payer. Rev Assoc Med Bras. 2013;59(3):248-53.

27. Erbel R, Lehmann N, Möhlenkamp S, Churzidse S, Bauer M, Kälsch H, et al. Subclinical coronary atherosclerosis predicts cardiovascular risk in different stages of hypertension: result of the Heinz Nixdorf Recall Study. Hypertension. 2012;59(1):44-53.

28. Oliveira BFA, Mourão DS, Gomes N, Costa JMC, Souza AV, Bastos WR, et al. Prevalência de hipertensão arterial em comunidades ribeirinhas do Rio Madeira, Amazônia Ocidental Brasileira. Cad Saúde Pública. 2013;29(8):1617-30.

29. Colosimo FC, Silva SSEB, Toma GA, Pierin AMG. Nursing actions increases the control of hypertensive patients and reduces white-coat effect. Rev Esc Enferm USP. 2012;46(n.esp):10-5.

30. Oliveira TL, Miranda LP, Fernandes PS, Caldeira AP. Effectiveness of education in health in the non-medication effectiveness of education in health in the non-medication hypertension. Acta Paul Enferm. 2013;26(2):179-84. 